\title{
ムービング・イメージと社会"
}

——映像社会学の新たな研究課題をめぐって——

\section{石田 佐恵子*}

今日の人びとの暮らしは, 圧倒的なビジュアル文化に埋め尽くされている. ムービング・イメージ，すなわち「移動する〈仮想〉の視線」を扱う社会学を， ここでは「映像社会学」と位置づける. 映像社会学とは, 方法・対象・実践と しての映像を総合的に考える領域と定義される. 映像社会学への関心は 1980 年代から次第に高まってきたが，より注目されるようになったのは，文化論的 転回以降の知的潮流と, デジタル化時代の新しい研究ッールとが合流する 90 年代後半のことである。この転回を受けて, 映像や図像の意味は本質化を疑わ れ，徹底的に文化的な構築物として捉え直されることになった。

本論では, 文化論的転回以降の映像社会学の研究課題が示される.すなわち, 映像制作と映像解読の双方の実践の場に研究する主体を置き, 两者を連続的な ものとして捉え直す，という課題である。こうした課題に近づくために，まず， 社会学的な映像制作に打ける諸条件が考察される. そこでは, 撮影する主体と 映像の移動性・流動性が強調される. さらに, 社会学的な映像解読の手法につ いて検討する. あわせて, グローバル時代の映像流通と受容とが議論される.

これらの作業を通じて, 視覚性の優位に特化した社会学的人間観を修正し, 多様なオーディエンス, ジェンダー化された身体や規格化されない身体にとっ ての「見ること+聞くこと」の経験を, より広い身体の領域へと拓いていくこ とが, 本論の目標点である.

キーワード：映像社会学, ビジュアル論的転回, 文化的構築物としての映像

\section{序}

モダニティについての多くの文献が言及しているように，19世紀から 20 世紀に かけて登場したさまざまな装置は, 人間の五感のうち「視覚の領域」を優位化し， 圧倒的に拡張してきた。新聞の抻絵印刷, 写真, 広告, 漫画, 店頭のディスプレイ に至るまで，さまざまなビジュアル文化装置が日常生活に大量に浸透した。 とりわ け，映画やテレビ，アニメや CGの人工映像，インターネットや携帯に流れる断片 映像など, さまざまなムービング・イメージが, 今日のビジュアル文化の中心を成

* 大阪市立大学大学院文学研究科教授 ishita@lit.osaka-cu.ac.jp 
している.

アン・フリードバーグは, それらの装置を「移動性をもった〈仮想〉の視線」と 特徵づける (Friedberg 1993=2008：3）．その含意は「移動する視線」と「〈仮想〉 の視線」の 2 側面に分かれる.

「移動する視線」それ自体は, 映像よりも古くから存在し, 人間の身体の移動, 散歩や旅行, 放浪, 移民や留学といった社会・文化的活動によって前景化されたも のである. その移動性は, 高速船・鉄道・車・飛行機・人工衛星といった移動通信 手段の発達に伴い, より速度を上げ，範囲を拡張してきた，船空・車空・機空から 移りゆく風景や街並み, 人びとの暮らしを眺めることは, 近代人にとって飽くなき 興味の対象であった。 そして, 社会学的思考においても, それらの空とその視野は, 社会認識の基礎イメージを形成する重要な役割を担ってきた（石田 2005）.

ポストモダンやグローバル化といった社会変動を論ずる議論において重要視され るようになったのは, 第 2 の論点, 「〈仮想〉の視線」の側面であろう.それは, 身 体のもつ時間的・空間的制約を超えた「想像上の」移動であり,「表象を介して受 け取る知覚」を意味する。映画やテレビは 20 世紀に新しく登場した空であり，「移 動する視線」の経験という意味でそれ以前の空と連続する.フリードバーグは,

「移動性をもった〈仮想〉の視線」が私たちの日常経験の中心を占めるようになっ たことで, 主体・記憶・身体のありようが深く影響を受けている，と主張する。も ちろんそれは, 社会学的主題にとってもきわめて重要な意味をもつ.

本論では, 視覚性を扱う社会学のなかでも, 特にムービング・イメージに焦点を あて, それを扱う社会学を「映像社会学」と呼ぶことにしよう。本論の目的は, 映 像社会学の担い手を, 映像制作の主体と映像解読の主体とに分断する枠組みを乗り 越え, 映像人類学や映像学, ビジュアル文化研究, メディア史, 美術史といった関 連諸領域と架橋する社会学的課題を明確に述べることである.

\section{1 ビジュアル社会学 /映像人類学 / 映像社会学}

\section{1 映像人類学の展開とその影響}

欧米圈の社会学において, ビジュアル社会学（visual sociology）という領域が浮 上するのは 1980 年代半ばである. 86 年に国際ビジュアル社会学会（IVSA）が発 足, 雑誌『Visual Sociology』 $\rrbracket^{2)}$ が創刊された. 同年の『Current Sociology』では, IVSAの発足にあわせて, 特集「ビジュアル社会学の理論と実践」が組まれている. 特集の編者, レオナード・M・ヘニーは,「ビジュアル社会学の歴史は社会学の歴 史と同じほど古く, 新しいのは名前だけだ」と述べ, 20 世紀前半から広く行われ てきた「写真や映画を用いた経験的な社会学」と 70 年代半ばのリバイバル・ブー ムとを接続している (Henny 1986a).

ヘニーは, ビジュアル社会学に影響を与えた重要な隣接領域として, 映像人類学 (visual anthropology), 社会史, 心理学的 / 精神分析学的視覚メディア研究などを 
挙げる，人類学では，その古典研究の多くが，民族誌資料収集の一環として豊富な ビジュアル資料を蓄積してきた，映画技術の発展と展開はそのまま映像人類学の歴 史でもあり，また，初期映画と民族誌映画（ethnographic film）制作は不可分の関 係にある. 民族誌映像の制作について人類学会で広く認知されたのは, 1973 年に シカゴで開かれた「国際人類学・民族学会議」でのことである.この大会では, 、 一ガレット・ミードやジャン・ルーシュを中心に映像人類学部会が立ち上げられ， 日本からはテレビ・ドキュメンタリー制作者の牛山純一と市岡康子らが招かれて出 席している (市岡 2005)。 また, その配付資料は『映像人類学』(Hockings ed. 1975=1979）と翻訳され，以降この訳語が定着してきた.

映像（image）という言葉は，本来「レンズを通して映し出された像」の意をも つ. 20 世紀前半には, 映像とは, すなわち写真と映画にほかならなかった。だが, テレビの登場以降, 静止像 (still image) と動画像 (moving image) の区別が一般 化し，今日では，映像とは「動画」を意味することが多くなっている．岡田晋は， visual anthropology が「映像人類学」と翻訳される含意として, それは「映像の 論理による新しい分野を拓く人類学でなければならない」と述べている. また, 単 なる資料収集の手段としてのみ映像を用いる場合には「視覚人類学」と訳すべき， とも加えている（岡田 1977）。1974 年には, テレビ制作者や映像作家などの専門 家が中心となって「映像民俗学を考える会 $\rfloor^{3)}$ が発足し，日本各地の失われつつあ る習俗・文化を撮影, 映像記録として発表してきた，その一方，人類学者による民 族誌映画制作, 研究実践としての映像人類学は浸透しない状況が続いたという（牛 島 1987).

こうした状況が大きく変わっていくのは，1990 年代以降のことである. ビデオ カメラやスチールカメラが小型化し, 研究者が調查地にそれらを携帯して調查資料 の収集を行うことが一般的になった，現在では，映像人類学の担い手も多様化し， その課題設定は多岐にわたっている，港千尋は，映像人類学にはいくつか異なる用 法があると指摘している（港 1999, 2001）。それは，(1)記録・資料収集ツールとし ての映像の利用，(2)映像の人類学，映像体験の人類学，(3)映像を表現手段とする人 類学, 研究成果としての映像作品, などである. 特に, (3)の研究成果としての映像 作品発表の広がりは顕著であり, 近年では, 学生による映像制作も増加 ${ }^{4}$, 日本文 化人類学会でも映像発表に特化した部会が設けられるなど, 一定の潮流をなしつつ ある (小坂 2002; 北村ほか編 2006 など).

\section{2 映像社会学の 3 つの課題設定}

映像人類学の展開に影響を受け, ビジュアル社会学の課題設定もさまざまに議論 されてきた，へニーは，過渡的なものと限定しつつ, ビジュアル社会学の定義とし て次の 5 つにまとめている. すなわち，(1)見ることをめぐる社会的要因の探求，(2) メディアにおける社会的イメージの構築, (3)社会的相互作用における視覚的側面の 研究，(4)視覚芸術の社会学，(5)視覚技術と社会組織，である (Henny 1986b). 
1980 年代には, 当時普及が進みつつあった家庭用録画機器やポータブル・ビデ オカメラなどを用いた社会学的研究が試行的に進められた。 たとえば，エスノメソ ドロジー的実験や質的社会学の実践研究, 映像ナラティブ分析などの研究があげら れる.これに対し, IVSA 会長（1996 年当時）ジョン・グラディは, ビジュアル 社会学を質的研究の一部と見なす枠組みは狭すぎる, と批判し, それは, (1)「見る こと」そのものの社会的構築をめぐる研究, (2)図像的コミュニケーションに焦点を あてた研究, (3)映像的な社会学実践, の 3 つを総合的に含みうる幅広い研究領域で ある，と規定している（Grady 1996）.

日本語での研究展開に視点を移すと, 1988 年に, 亘明志と田邊信太郎によって, visual sociology が「映像社会学」と訳され，体系的に議論されている5)。彼らによ れば, (1)研究方法としての映像, (2)実践としての映像, (3)研究対象としての映像, の 3 つの問題領域が区別され，それぞれ映像人類学・非言語的コミュニケーション 研究, 心理学・教育学・体育学などの映像コミュニケーション研究, 臨床社会学な どの実践研究が例示されている（亘・田邊 1988）。それ以降，ビジュアル社会学を 体系的に展開する試みは多くはないが, 田畑暁生による映像社会学の理論化の試み （田畑 2001）や，安川一による「視覚社会学」の提唱（安川 2002）などが挙げら れよう.

本論では, 特にムービング・イメージを扱う領域を「映像人類学」とつながる観 点から「映像社会学」と規定したが, この言葉は, 映像解読と映像制作の 2 つ対 極的な含意に引き裂かれているため, 注意が必要である.

一方で，映像社会学は「映画の社会学」と同じような意味で使われ，「映像を対 象とする社会学」が展開されてきた。 また, 同様に「テレビの社会学」も映像を対 象とするが, ジャーナリズム研究やマス・コミュニケーション研究として展開され る研究が多く，第 3 節で述べるように，映像そのものを扱った研究はむしろ少ない. 他方で，映像制作を実際に行う科目や映像を用いた社会学教育が「映像社会学」 という名称で近年開設されており，映像人類学と同じように「異文化理解」や「フ イールドワークの実践」として映像制作を行う科目，市民メディアの担い手となり 「社会運動や自己表現の一環」として映像制作を目指す科目などが含まれている. このように，現状では，映像社会学はさまざまに分断され，まとまりのある領域と してイメージしにくい.

そこで，本論ではこの分断を統合し，映像社会学を 3 つ課題設定から捉え直す 立場を採る。すなわち，方法・対象・実践としての映像を総合的に考える，という ことである6).

（1）「記録としての映像」：写真や映像（カメラ／ビデオカメラ）によって資料を 記録し，その資料から社会学的な考えを組み立てていくという方法.

(2)「映像の社会学」「映像体験の社会学」: 映像そのものが近代社会にとってど ういう意味をもってきたのか，または，現代社会の構成に映像がどのように関 わっているのか, それらを根源的に問いなおそうとする試み. 
（3）「映像を表現手段とする社会学」：論文のみを研究成果とするのではなく， 「映像そのもの」もまた研究成果と考え, 研究実践として映像制作を行う社会 学.

このように映像社会学の課題を考えると, 感情社会学や文化社会学, 記憶の社会 学はもちろん, 教育社会学, 家族社会学, 医療社会学, 労働社会学, グローバル社 会学など，多様な社会学的主題が映像社会学の対象となりうる.

\section{2 文化論的転回以降の映像社会学}

\section{1 ビジュアル論的転回}

1990 年代以降の技術的基盤の変容は, 研究手法だけではなく, 社会学の研究対 象，すなわち，さまざまな社会現象や人びとの暮らしにも多大な影響を及ぼしてい る. 携帯電話のカメラ利用を含むデジタル機器類の圧倒的な普及が，集合的記憶の ありようや旅のスタイル，ニュース報道のモードといった社会全域に及ぶ視覚経験 を劇的に変化させている，それに伴い，人文諸科学において，ビジュアル文化への 関心が爆発的に広がっていった。

それらの潮流のなかで，本論にとって重要なのは，カルチュラル・スタディーズ と接合する立場, すなわち, 自然科学的な普遍性をもつものとして記号や象徵, 図 像などの知覚をとらえるのではなく，それらの意味・解釈はきわめて文化的な構築 物である，という論点である。この認識の変化は,「文化論的転回（cultural turn)」になぞらえて「ビジュアル論的転回（visual turn）」と呼ばれる（Jay $2002 a)^{7)}$. また, その後の研究動向について「文化論的転回以降のビジュアル研 究」という表現が用いられることもある（Dikovitskaya 2006）。

文化論的転回とは，現在では人文諸科学全般に広がったパラダイム転換，言語論 的転回（linguistic turn）や解釈学的転回（interpretive turn）の文化研究における 応用概念と位置づけられる（Chaney 1994；吉見 2003）。それは，端的に言えば， 「社会や文化はそれらを解釈し語る営みから構築されるものであり，言説的な構築 の場を離れて論じることはできない」という主張である。文化研究におけるパラダ イム転換によって，高級文化，教養層の形成，国民国家的文化，本質主義的文化と いった諸概念は解体され，同時に，それらと対比的に議論されてきた，大衆文化， ポピュラー文化，民族文化といった概念もまた，その根底から再定義を求められる ことになった

こうしたパラダイム転換は，ビジュアル文化研究の対象や枠組みにも深く関連し ている. ビジュアル文化研究の対象の多くは，美術史や芸術，文化財などの「高級 文化」に属すると見なされてきたものか，あるいは，映画（特にハリウッド映画や ディズニーのように大量配給される国籍性をもった映画），テレビ番組，アニメー ションなど，大衆文化，マス・カルチャー，ポピュラー文化として論じられてきた ものである。これらのビジュアル文化は，一旉でに高級芸術／ポピュラー文化の 
区別は意味を成さなくなっているのであるが——, 誰にとっても等しく同じ意味を 伝えるものでは決してない，誰が/いつ/どこで/どのようにして／制作・構成し /受容・解釈するかによって, まったく異なった意味を生みだすものなのだ.

第 1 節で述べたように, 映像社会学の課題設定には, 方法・対象・実践の 3 つが ある. ビジュアル論的転回の議論を受けて，それぞれの側面について，文化的構築 物としての映像概念を導入することが必要なのである.

\section{2 文化的構築物としての映像}

では, 映像を文化的構築物として考えるとはいかなることなのか. そもそも, 映 像とはきわめて文化的なものであり, 映像言語の研究に見られるように, 言語に類 する構造と体系をもつものと考えられてきた. しかし, 他方では, 図像やイメージ の知覚に関して, 文化的差異を超えた自然科学的普遍性が想定されてきた.

たとえば, 日本映像学会では, 映像の定義として,「知覚の表層」から「意識の 深層」へと 4 層に分け，そのそれぞれに「主体領域」と「客体領域」を想定してい る（浅沼ほか 1977），そこでは，文化現象としての映像は，その最も基底を成すも のと考えられている.

また, 佐々木成明も, 映像を「ビジュアル・フィールド」と「ビジュアル・ワー ルド」とに区別して論じている，前者は, 網膜に映る像, すなわち「絶えず移り変 わる外界の光の連続パターン」であり, 脳科学の研究対象となる. 後者は, 人間が 「見ている」像であり，そこに意味を見いだし「自ら作り上げている世界」とされ る（佐々木 2005: 10). 映像社会学が対象とするのは, 文化的に構築された「ビジ ユアル・ワールド」だが, 両者の境界をどこに引くか, 分析において区別すること は容易なことではない。

ミーケ・バルは，ビジュアル文化研究に蔓延する「ビジュアル本質主義（visual essentialism)」を手厳しく批判する, バルによれば, ビジュアル本質主義とは, 映 像の〈本質〉を読むこと, 視覚上の〈差異〉を宣言すること, あるいは, 他のメデ イアや記号論システムに対して〈視覚性の領域〉を独占したいという欲望, として 現れるという（Bal 2003）。それは, 〈視覚性〉というものが文化とは独立して存在 し, ビジュアル・テクストや「見ること」に関して人類に共通不変の部分が存在す る, という前提である，バルは, ビジュアル本質主義は, 従来の美術史やビジュア ル文化研究の対象を限定し, それぞれの学域の境界維持に寄与し, 方法論的な越境 性が拡がるのを妨げてきた，と指摘する ${ }^{8)}$.

このような〈視覚性〉の本質化への批判は, 文化本質主義やジェンダー本質主 義9), 構築主義論争などと論点を共有する, より大きな社会理論と関係するもので あり, 軽々に決着させることのできない深さと広がりをもっている.ここでは, 映 像社会学の重要な論点のひとつとして, ビジュアル本質主義の主張を意識し, これ まで想定されて来なかった「見ること」の根底にかかわる範囲にまで文化的構築の 観点を導入することで, 新しい映像社会学の研究課題を提唱する. 続く 2 つの節で 
は，社会学的研究を実践する主体として，映像制作と映像解読の立場についてそれ ぞれ議論する. 社会学的な映像制作／映像解読というものが可能であるとするなら， それはそれぞれいかなる条件を満たすことが必要なのか.

\section{3 観察・記録・撮影する主体一一社会学的映像制作は可能か}

\section{1 透明な撮影者の否定}

映像社会学の第 1 の課題設定は, 研究手法として映像撮影を行い, それを資料や データとして活用・分析し, 社会学的考察に用いることである. また, 第 3 の課題 設定には, 研究成果としての映像制作実践が含まれる。ここでは, 両者を併せて議 論していくことにしたい.

調查対象を観察・撮影する際に問題となるのは, 研究主体と調查対象者との関係 性にあることは，一般の社会調査となんら変わるところはない。むしろ，カメラと いう道具を媒介とする映像社会学は，その関係性の問題を鋭角的に露わにする。 ま ずここでは, いくつかの事例を基に, 社会学的研究実践としての撮影や映像制作が どのように可能であるのか, その前提条件について考えてみよう.

民族誌映像では，人類学本来の「他文化・他者を撮影する」という伝統が存続し ているが，近年では，それに対する批判的な潮流として「自文化・自身を撮影す る」という枠組みも盛んに採用されている（El Guindi 2004）。社会学者が研究実践 として映像を撮影するときにも，社会における「他文化・他者」を対象にする場合 と「自文化・自己」を対象にする場合とがあるだろう，そう考えれば，民族誌映像 祭で上映されている作品は, 調査地選択の差こそあれ, そのまま社会学者の研究実 践であってもなんら不思議ではない.

そこで常に問題となるのは，誰／何を対象とするにせよ，それが「誰の視線によ って」撮影されているのか，ということである.

小林義寛は，映像制作による社会調査を早くから意識していた社会学者の一人た が, 富山県八尾の「風の盆」を撮影した経験から, 進行中の状況に対して「撮影と いう介入」がどのようにかかわるのか議論している. よく知られているように, 1960 年代には，撮影する主体の位置をめぐって 2 つの対称的な手法が出現した. ひとつは, ダイレクト・シネマと呼ばれ, 観察映画に代表される「客観的」な映像 であり, 撮る主体（カメラ）がフレームに写りこむことなく, どこまでも透明な存 在として撮影するものである.もうひとつは，シネマ・ヴェリテと呼ばれる手法で， 状況に積極的に関与し,「参加するカメラ」がしばしば映像のなかに写りこんでい くものである (大森 1982)。「透明な観察者＝研究者」のモデルは，民族誌映像の 制作現場に長く維持されたが，次第に，研究者による「観察する視点の独占」への 批判が高まり，撮る主体と撮られる主体の断絶した表現形式はその根底から疑われ ていくことになる，小林は，こうした民族誌映像の変革を受けて，撮る主体と撮ら れる主体の相互干渉・再交渉・新たな関係性の模索，というプロセスとその実践を 
社会調査に取り入れることを提案している（小林 1993）.

映像人類学者の村尾静二は, 民族誌映画の制作意図, フィールドワークとそれを 撮影する行為, 映像素材の編集, それぞれの制作過程について, 可能な限り「映像 の一部として」提示することが重要であるという．民族誌とは「文化を写したも の」, ドキュメンタリーとは「社会的事実を提示するもの」, と単純に仮定されがち だが，それらは決して独立した「客観的事実」ではない，民族誌映像やドキュメン タリーもまたある種の「フィクション」なのであり（佐藤 2007）, 制作者の意図や 特定の条件, 編集の結果, 紡ぎ出される構築物である. 現在の民族誌映像制作にお いては, 撮影現場に行き交う視線のポリティクス, 撮影プロセスが, 映像の内部に 提示されているか否かが重要な論点のひとつとなっているという（村尾 2006）. 社 会学的映像制作が可能であるのなら, それは, 村尾の提起する問題, 映像表現の一 部としてその制作プロセスが検証可能な形で提示されていることが, 最低限の条件 と言えるのではないだろうか.

丹羽美之は，授業において映像を用いたフィールドワークを実践しているが，そ

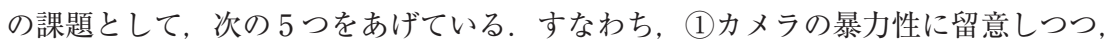
撮影される主体との関係性をつくりあげること, (2)支配的な映像文化の影響力につ いて考察すること, (3)映像表現の多様性の探求, (4)グループワークの重要性, (5)完 成した作品の社会における共有, である（丹羽 2008）。文化的構築物としての映像, という本論の脈絡から言えば, 最も関連するのは, (2) と(3)である. 初心者が制作し た映像であっても，テレビや映画で慣れ親しんだ映像文法が意眓せず多用されてい ることに気づき，驚くことがある．映像を見ることが日常化している時代には，こ のような映像表現の文法が自然に身に付いていることが珍しくない．また，私たち が映像を見て「分かりやすい」とか「面白い」と感じる, その感性それ自体が, 支 配的な映像文化によって構築されているとも言える.

繰り返しになるが, ドキュメンタリー映像制作の模倣ではなく, 社会学的な映像 制作が可能であるのなら，それには，社会調査における調査過程の明示規則と同様 に, 撮影手法・制作プロセスが映像表現のなかに露呈していることが求められる. 撮影する主体＝研究者の姿がファインダーのなかに露わになるとき, そこには, 撮 影される主体との相互干渉・視線の交差もまた映し出される，そして，研究者は， カメラの向こうで「見ること」に特化した透明な主体ではなく, 五感を伴った具体 性を帯びた身体として登場するはずである.

さらに，文化的構築物としての映像を考えるとは，制作者の意図，制作プロセス の細部を露呈化することだけではなく, 映像言語の成り立ちにまで遡ってその構築 性を考察することにほかならない. その考察にとって重要なのは, 制作された映像 がどのような空間で上映され, 解読されるのかにかかわる想像力である.「誰の視 線によって」撮影されているのか, 撮影者の立ち位置が明示された映像は, 研究す る主体を, 必然的に映像を制作する側から解読する側に迎え入れることになる. 


\section{2 ムービング・イメージの流動性}

冒頭で述べたように，本論では，テレビや映画，携帯動画，街頭のディスプレイ に至るまで，私たちの生活をとりまく映像環境全般を「ムービング・イメージ」と 呼んでいる，この概念を用いるのは，フィルム，ビデオ，テレビ，デジタル画像， といった技術決定論的用法を避け，映像の固定された意味や，特定の社会に支配的 な映像文化を自明の前提としない場所から議論を始めたい，という意図を込めての ことである.

ジェームズ・クリフォードに代表されるポストモダン人類学には，3つの共通す る論点があるとされる。それは，文化内の同質性の否定，文化本質主義批判，民族 誌を書くという行為の特権性への疑い, である（Rosaldo 1989=1998; 桑山 2006）. 映像人類学会では，こうした新しい潮流からの批判に応えるための撮影や編集のあ りようが議論され, 新しい映像表現が模索されている（EASA Visual Workshop 2005).

映像社会学においても, 映像を制作する主体としての研究者の位置をめぐる議論, その課題はポストモダン人類学と共通であると言えるだろう。支配的な映像文化を, 同質的な共有性をもつもの=自明の前提として扱うのではなく，それらを相対化す るような枠組みを撮影手法や映像表現に組み込んでいく姿勢が重要なのである.

しかしながら，映像制作を実践的に試みようとする場合, 現在流通している映像 編集教本などには, このような類の記述はほとんど見あたらない10). 自明の前提 として，テレビ的な，意味の「安定した」文法や文体による撮影と編集が推奨され ている.

たとえば，撮影する主体と撮影される主体との関係性を描く要素として，当事者 に近づくことができないとき遠方から音声をどのように録音するか，三脚を使用し 固定点から撮影するか否か，などの撮影技法をめぐる選択肢がある．教科書で採用 されているのは，いかに専門家的な映像表現に近づくかであり，それがオーデイエ ンスに向けての「分かりやすさ」を保証する様式と見なされている．だが，視点を 固定させて距離を置いて対象を撮る，という撮影方法は，ある種の文化的枠組みに よる習慣にすぎない.

また，一般的に「映像作品」には，タイトルとエンドロールがあり，一定の時間 枠で意味のあるまとまりとして制作されている，映像のフォーマットも，ある程度 共通性をもち，あらかじめ定められている，だが，もちろんそれらも，ある時代や 社会に限定的なものであり，技術上の制約をもった文化的構築物であることに留意 しておく必要がある.

強調しておきたいことは，撮影や編集といった映像制作実践は，研究する主体の 位置を移動させながら記録する営みを含んでいる点である。リキッド・ライフと呼 ばれる社会状況のなかで，人びとの主体は流動化し日々その位置を変えている (Bauman $2000=2001,2005=2008)$ ）そして，そのありようを研究＝撮影しようと する主体もまた，視線や声の届く範囲，立ち位置を変え，対象との関係性を変化さ 
せながら移動していく.

このようなモデルは, 透明な撮影者=研究する主体, 固定された文化の実践者 $=$ 撮影される主体, という図式を変更する. 動くイメージを捉えるビデオカメラは移 動性を記録するのに向いているが, 撮影者自らが都市を移動しながら携帯画像を記 録していくという手法（たとえば, Solomon 2007 など）や, 交差する視線を表現 するための複数のカメラの導入など, さまざまな実験的手法 ${ }^{11)}$ が試みられている.

\section{4 解読・受容・創造する主体一一社会学的映像解読の手法}

\section{1 映像解読と分析手法}

映像社会学の第 2 の課題設定は, 映像を対象とする社会学であり, 映像そのもの の意味の探求, 社会における映像経験を吟味し分析する, というものである。映像 制作実践に比べて，映画やテレビ番組などを分析・研究対象とする社会学は，ある 程度の厚みをもってすでに展開されてきている，だが，その分析手法は，記号論， 映画研究, 映像学, 物語分析などの影響を受けて多様であり, 最近では学際領域・ 複合領域としての展開も顕著ではあるが, 旧来の社会学やマス・コミュニケーショ ン研究の手法とは相違もある。ここでは, 文化論的転回以降の映像社会学が必要と する分析手法をまとめておこう。

カルチュラル・スタディーズの立場から映像分析手法を解説したリスターとウェ ルズは, 分析ポイントとして次の点を挙げる. まず, エンコーデイング／デコーデ イング・モデルと同様, 映像テクストに対して, 制作のコンテクストと見るコンテ クストの 2 つが焦点化される。 また, その意味生成には, 慣例 (conventions) の 作用が大きくかかわり，図像的慣例／記号論とコード／写真的慣例／社会的慣習 · 表象などの各レベルにおいて, 詳細に分析項目が設けられる（Lister and Wells 2001).

また, テレビ・ドキュメンタリーの記号論分析を行っているイエデマは, 映像分 析を, (1)フレーム, (2)ショット, (3)場面, (4)シークエンス, (5)ジャンル, (6)全体, の 6 レベルで展開している (Iedema 2001).このように, 近年のテレビ研究では, 番組のなかの一部の映像クリップについて範囲を定めたうえで, それを詳細に記述 し，図表化して分析するという手法が広がっている.

こうした手法は, マス・コミュニケーション研究における「内容分析」とは異な る水準を分析の目標としている．テレビニュースの「ディスコース分析」を行って いる伊藤守によれば，その手法は 2 つの点で従来とは異なるという．第 1 に，二ュ ースが社会的事実を「正しく」報道しているのかを問うのではなく，ニュースによ って「社会的現実が構築されている」という前提から分析する, という点. したが って，表象の細部が社会的現実の構築にどのようにかかわるのか，が分析の焦点と なる、第 2 に, 文字や文章を中心とする「内容分析」ではなく, 映像・音響・背 景・文字という複合的な要素を総合して「マルチモダリティ分析」を行う点. 複合 
的要素を詳細に分析することで, 複雑な意味構築過程を記述することが可能になる (伊藤編 2006).

つまり，新しい映像社会学の手法は，映像の意味構築のレベルから根源的にその 構築性を探求するという点で共通し，映像を徹底的に文化的構築物として扱うので ある。

先行する映画研究の影響を受けて，ある時期までの映像社会学の先駆的なイメー ジは「映画の社会学」であった（たとえば，山中ほか 1993; 井上ほか 1999 など）. 映画は，テレビ番組に比べて資料入手が容易であり，パッケージ性が高く独立した 「作品」として鑑賞される傾向がある。そのためか，「映画の社会学」の多くは，映 画の「あらすじ」を紹介し，社会学や関連領域の命題を解題するという手法を採用 している．映像そのものに言及している社会学的研究は意外なほど少ない。つまり， 確かにそれらは「映像を対象とする社会学」ではあるのだが，手法として「物語の 社会学」であって「映像の社会学」とは捉えにくいのである.

長谷正人は, このような「映像の社会学」の枠組みに対して, 別の「映像の社会 学」の方向性を提案している。長谷は，映像を「製作者によって主観的に解釈され た『現実』の『間接的反映』」と捉えるのではなく，「社会に開かれた表現，映像を めぐるコミュニケーションのなかに存在するもの」として捉えるべきだと述べる (長谷・中村 2003).

メディアと社会との関係は，「メディアが社会の鏡である」というような単純な 反映関係ではない（石田 2000）。映像テクストのなかに規範や慣習，価值や意味の 世界を見いだし，それを解読する分析とは，社会学的探求を通してすでに社会学者 たちが「知っていた」ことの「映像による確認」にすぎないのであり，その意味で， 同義反復的なものとならざるを得ない，長谷が述べるように，映像が生まれ，流通 し，視聴される社会的空間とその配置について詳細に考察する必要がある．映像社 会学にとって忘れてはならないのは, 映像の置かれた場所には, 必ず制作と流通の 論理が不可分に絡み合い，特定の場所・時に具体的な誰かがそれを見ている，とい う観点である，映像制作実践と同じように，映像解読実践においても，誰がどのよ うな位置からそれを行っているのか，という問題が重要となる．社会学的命題をあ てはめつつ映像を解読する者＝研究者, というモデルは, 結局のところ, 映像テク ストに対する単一の（時に特権的な）読みを提示することに留まる．新しい映像社 会学の課題, すなわち, 映像言語の成り立ちにまで遡ってその構築性を考察し, 支 配的な映像文化そのものを問い直し社会における映像経験を再吟味し分析する， か らすると，そのモデルは再検討される必要がある.

こうして，映像言語の成り立ちゃ映像制作のコンテクストを注視し，映像解読の 空間を吟味する映像解読実践は，研究する主体を，解読するだけの側から制作する 側へと，あるいは，制作者たちとの相互対話の場所へと，いざなうことになるだろ う. 


\section{2 グローバル化時代の映像解読}

映像による社会的現実の構築は, 映像・音響・背景・文字という複合的な要素が 複雑に絡み合って成立している。 これは, 映像の「複合経路化」と呼ぶべき特質で あるが, もうひとつの重要な特質は, 映像が私たちの日常生活を丸ごと覆い尽くし ているという感覚, 「泡括環璄化」という特質である（佐々木 2005）。この 2 つの 特質は, テレビが社会全域に広がった時代から次第に感覚されるようになり, さら に, 街頭の大きな広告ビジョン, 電車のなかの映像, 携帯機器類といったさまざま な映像メディアの汇濫によって, いっそう強まっている.

映像の「包括環境化」が進んでいくことで, 誰が/いつ/どこで/どのようにし て見ているのかについてのイメージ，すなわち，オーディエンス像は，より「見る こと」に特化した〈透明な存在〉に近づいていく，映画が「映画館で」見られてい た時代, 暗がりの座席から「見ること」のみが前景化し, オーディエンスは「作品 を鑑賞する」存在として語られ，その人物がどのような身体をしているのか，暗が りの中で食べたり居眠りをしたりしている，といった経験は後景に追いやられてき た (Hastie 2007)。〈視聴率〉という魔術的な数字が支配するテレビ産業界では, 性別・世代別の抒扰まかな分類こそあるものの, 想定されているのは平均的な嘹好 性をもつ多数派の（大都市に住む）視聴者像であり，個別の差異は考慮されること がないのである（石田 2007a）。

1990 年代後半以降の変化で重要なのは, 映像解読を行う主体もまた, デジタル 化とグローバル化の影響を受けているという点である.

デジタル化に関して言うと, 最も顕著な影響とは新しい映像解析手法の広がりで あろう、VH Sテープなどに録画してデー夕収集を行っていた時代には，その分析 には膨大な時間を必要とした，近年，ハードディスクに映像保存する技術が一般化 したことで，映画にせよテレビ番組にせよ，データとしてコンピュータに取り込み， 映像・音声編集ソフトを用いて個々の映像表現を分析することが容易になった，映 像表現の国際比較が進められ，たとえば，英語圈で好まれるカット数と日本でのカ ット数が異なる, などの「発見」があり, これらの映像表現パターンはある種の 「映像文化」とみなされている（小玉編 2008）。20世紀は，映像文化が国境を越え て流通し，共通領域を拡大してきた時代である，それは，文化帝国主義的な枠組み から見ると,「文化の均一化と支配」にほかならないが, 映像による意味構築, 映 像テクストによる現実世界の構築という観点からより微細に分析することで, 個々 の地域や場所によって異なる「グローカルな映像文化」に注視することができる (石田 2003)。 そのような比較研究からは, 異なる場所で／異なる視線から, 映像 を解読することの重要性が示される.

このように, 映像経験についてのもうひとつの重要な変容は, グローバル化の進 行である. 国境を越えた映像流通という現象が, ますます多くの研究者の関心を集 めるようになっている，映画の場合，20世紀全体を通して，国境を越えた流通と 受容とが進行してきた。それは，ハリウッド映画のような強大な映画産業の発展を 
背景に，資本と制作，流通を独占する国家的装置と等置されてきた。これに対して， テレビ・メディアは, 第二次世界大戦後の 30 年間, きわめてドメスティックな映 像文化を形成してきた，日本の場合は特に顕著であるが，テレビは国民国家の境界 内で制作され視聴されることを前提としてきた．しかし，グローバル化の進行によ り，国内市場向けに制作された多くの映像作品が国境を越えて受容され，また逆に， 2004 年の〈韓流ブーム〉のように, 海外発の映像作品が大量流入するという現象 も起こっている (石田 2007b). 近年のより大きな変化は, インターネット上の動 画サイトに抏いて，国境を無化するような映像が，その制作者も出所も不明のまま 「流れて」いるのを目撃するようになったことである. それらの現象は, 時間も空 間も超え, どこでもない場所で誰でもない主体が映像解読を行うイメージを私たち にもたらしている.

新しい映像社会学は，こうした主体の位置，常に移動していく〈仮想〉のまなざ しと声とをめぐる経験を対象とする必要がある。「見る」経験のみが前景化すると き，ジェンダー化された身体，震えたり食べたりする身体，規格から外れた身体の 経験は後景化される，映画やテレビを見ることを標準規格化された経験から解き放 ち, 視覚以外の感覚する身体をいかに社会学的思考に回復することが可能なのか.

それには, 支配的な映像文化の内部に留まって映像を解読することからは見えて来 ない枠組みが必要となる。ニュース配信の現場では, 新聞やテレビといった旧来の メディアの枠を超え, また, 身体的にも思考的にもつねに国境を移動しながら情報 収集と発信を行う，一群のジャーナリストたちが注目されている．彼ら・彼女らは 「越境的ジャーナリスト」と呼ばれる存在であるが, 映像解読実践を行う社会学者 もまた，映像文化を越境し，その立場を変えながら分析を行うことが求められてい るのである.

\section{結}

本論では, ビジュアル論的転回以降の映像社会学の研究課題が示された。それは, 映像制作と映像解読の双方の実践の場に研究する主体を置き, 両者を連続的なもの として捉え直す, という課題であった。 まず, 社会学的な映像制作が考察され, 制 作プロセスの細部が映像表現として露呈していることが重要であること, さらに， 映像言語の成り立ちに遡って構築性を考えることが重要であることが示された．ま た, 社会学的な映像解読の手法については, 支配的な映像文化そのものの問い直し を含んだ分析が必要であることが強調された。こうして,「映像を方法とする」映 像制作,「映像を対象とする」映像解読の，2つの社会学的実践は, どちらから出 発しても連続的なものとして展開される必要があることが明らかになった。なお, 本論では, 映像社会学の第 3 の課題設定, 研究成果の表現・発信方法において「映 像実践を含んだ」社会学について，充分な議論を展開する紙幅が残されていないた め, 別稿に機会を改めることにしたい. 
本論は, 今後多くの映像社会学的実践が展開された後に, 再び検討される必要が あるだろう。映像による研究成果発表機会の増大, 映像祭や資料映像アーカイブズ の発展が大いに研究に影響を及ぼすに違いない. 制作されるべき社会学的映像テー マも, 分析・解読されるべき映像資料も無数に残されている. その意味で, 映像社 会学は始まったばかりとも言えるだろう.

本論では, 映像社会学の新しい研究課題をめぐって議論を展開してきたが, それ は, まったく新しい課題を提示したというより, この領域に深い関連性をもつ, 映 像人類学, カルチュラル・スタディーズ, メディア・リテラシー実践などによって もたらされた果実を, 改めて社会学の研究課題として捉え直す試みであったかもし れない. バルが主張したように, 学域の境界をそれぞれ強調することは, 応用可能 な研究手法の越境的な使用, 研究法の発展の妨げにしかなりえないであろう. 私た ちに必要なのは, 専門特化した研究領域を守ることではなく, ムービング・イメー ジという魅力的な概念を新たに社会学内部へと招き入れる姿勢にほかならない.

\section{[注]}

1）この論文タイトルは，2006 年に私たちが開催したシンポジウムと同名であり，それに触発さ れたものではあるが, 内容的に重複するものではない，詳しくは，(映像社会学研究会ほか 2007）を参照.

2） 2002 年に誌名が Visual Studies に変更された.

3） 1977 年から「日本映像民俗学の会」と改称.

4）イギリス人類学会（Royal Anthropological Institute）に付属する国際民族誌映像祭（RAI International Festival of Ethnographic Film）は，1986 年から隔年で開催され，2009年で11 回 大会を迎える. 1990 年以降は, 学生作品部門も設けられ, 各国から数百の応募がある.

5）同書の文献リストには, 国際ビジュアル社会学会に関する資料はないが, 1970〜80 年代にか けて出版された関連書物がいくつか挙げられている，また，冒頭には次のような記述がある. 「映像社会学（visual sociology）という名称は，ときどき使われるようにはなったけれども， それがどのような方法で何を対象とするのか，については定まった共通了解事項というものは ない」(亘・田邊 1988: 7).

6）近年発足したイギリス社会学会の分科会, 映像社会学研究部会 (Visual Sociology Study Group）では,「映像社会学」を「社会生活における映像的側面についての社会学」と定義し, その理論と方法を研究方法・研究対象・研究実践の観点から, やはり 3 点にまとめている (BSA 2007).

7）ビジュアル論的転回（visual turn）は，フォスターの編著（Foster ed. 1988）に端を発する 概念とされ，時には「画像的転回（pictorial turn）」と呼ばれることもある（Jay 2002b）.

8）バルの提起した論点に関しては, 次号で特集が組まれている（Mirzoeff 2003 ほか).

9）ジェンダー本質主義／ジェンダー構築主義とメディア研究との関係については（石田 2000） を参照.

10）例外的・先駆的著作として，（山中 2009）を参照.

11）ここでは, 社会学者が「撮影・制作の主体として」映像を利用する事例を考えているので, ノン・フィクションを中心に扱っているが, もちろんフィクション映画を対象とする映像社会 
学も存在する. また, 民族誌映像には, 当事者に演じてもらう「エスノ・フィクション」など の手法もある（Sjöberg 2007）.

\section{[文献]}

浅沼圭司ほか, 1977, 「映像学への道」『季刊映像学』日本映像学会, 7: 2-15.

Bal, Mieke, 2003, "Visual Essentialism and the Object of Visual Culture," Journal of Visual Culture, 2 (1) : 5-32.

Bauman, Zygmunt, 2000, Liquid Modernity, Polity Press. (=2001，森田典正訳『リキッド・モダニ ティ』大月書店. )

——, 2005, Liquid Life, Polity Press.（=2008, 長谷川啓介訳『リキッド・ライフ—現代にお ける生の諸相』大月書店.)

BSA: British Sociological Association, Visual Sociology Study Group, 2007, http://www.visualsociology.org.uk/ (2007/02/02).

Chaney, David, 1994, The Cultural Turn, Routledge.

Dikovitskaya, M., 2006, Visual Culture: The Study of the Visual after the Cultural Turn, MIT Press.

EASA Visual Workshop, 2005, The Frontiers of Visual Anthropology, at 9th RAI International

Festival of Ethnographic Film, University of Oxford.

映像社会学研究会＋大阪市立大学 UCRC アーカイブス・プロジェクト，2007, 『シンポジゥム「ム

ービング・イメージと社会」報告要旨集』大阪市立大学都市文化研究センター.

El Guindi, Fadwa, 2004, Visual Anthropology: Essential Method and Theory, AltaMira Press.

Foster, H. ed., 1988, Vision and Visuality, Bay Press.

Friedberg, Anne, 1993, Window Shopping: Cinema and the Postmodern, The University of California

Press. (=2008, 井原慶一郎・宗洋・小林朋子訳『ウィンドウ・ショッピング——映画とポス トモダン』松柏社. )

Grady, John, 1996, “The Scope of Visual Sociology,” Visual Sociology, 11(2) : 10-24.

Harper, Douglas, 1998, “An Argument for Visual Sociology,” Jon Prosser ed., Image-based Research:

A Sourcebook for Qualitative Researchers, London: Falmer, 24-41.

長谷正人・中村秀之, 2003, 『映画の政治学』青弓社.

Hastie, Amelie, 2007, “Eating in the Dark: A Theoretical Concession," Journal of Visual Culture, 6 (2) : 283-302.

Henny, Leonard M., 1986a, “A Short History of Visual Sociology,” Current Sociology, 34(3) : 1-4.

- 1986b, "What is Visual Sociology?" Current Sociology, 34(3) : 46-51.

Hockings, P. ed., 1975, Principles of Visual Anthropology, Mouton. (=1979, P. ホッキングズ, 牛山 純一編, 石川栄吉監修, 近藤耕人翻訳監修『映像人類学』日本映像記録センター.)

市岡康子, 2005, 『KULA一一貝の首飾りを探して南海をゆく』コモンズ.

Iedema, Rick, 2001, “Analysing Film and Television: A Social Semiotic Account of Hospital: An Unhealthy Business," van Leeuwen, Theo and Carey Jewitt eds., Handbook of Visual Analysis, Sage, 183-204.

井上輝子ほか, 1999, 『ビデオで女性学』有斐閣.

石田佐恵子, 2000,「メディア文化研究に打けるジェンダー あるいはジャンル研究の含意」吉見 俊哉編『メディア・スタディーズ』せりか書房, 113-27.

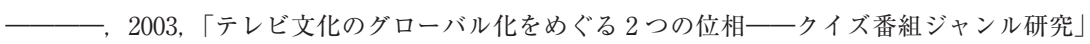


『思想』956: 114-32.

——, 2005, 「移動する媒体と経験の速度」『ソシオロジ』50(2)：139-47.

，2007a，「世代文化論の困難——文化研究における『メディアの共通経験』分析の可能

性」『フォーラム現代社会学』関西社会学会, 6: 35-44.

——, 2007b,「韓流ブームのさまざまな語り手たち——他者表象と越境する文化」石田佐恵

子・木村幹・山中千恵編『ポスト韓流のメディア社会学』ミネルヴァ書房, 1-31.

伊藤守編, 2006, 『テレビニュースの社会学』世界思想社.

Jay, Martin, 2002a, “That Visual Turn,” Journal of Visual Culture, 1(1) : 87-92.

—, 2002b, “Cultural Relativism and the Visual Turn," Journal of Visual Culture, 1(3) : 267-78.

北村皆雄・新井一寛・川瀬慈編, 2006, 『見る, 撮る, 魅せるアジア・アフリカ!一映像人類学

の新地平』新宿書房.

小林義寬, 1993, 「映像人類学と社会学——映像による社会調查の試み」『社会学論叢』日本大学社

会学会, 118: 57-70.

小玉美意子編, 2008, 『テレビニュースの解剖学』新曜社.

小坂亜矢子, 2002,「レンズを通して—人類学における映像の可能性」『年報人間科学』大阪大学

大学院人間科学研究科社会学 · 人間学 · 人類学研究室, 23: 115-26.

桑山敬己, 2006,「ポストモダンの人類学」綾部恒雄・桑山敬己編『よくわかる文化人類学』ミネ

ルヴァ書房, 176-7.

Lister, Martin and Liz Wells, 2001, “Seeing Beyond Belief: Cultural Studies as an Approach to

Analysing the Visual," van Leeuwen, Theo and Carey Jewitt eds., Handbook of Visual Analysis,

Sage, 61-91.

港千尋, 1999, 「映像の自然」伊藤俊治・港千尋編『映像人類学の冒険』せりか書房, 10-20.

，2001，「港千尋 $\times$ 管敬次郎対談」『JUNKU 連続トークセッション 2001 年 12 月 8 日

(土)』http://www.inscript.co.jp/minato/01.html (2007/02/02).

Mirzoeff, Nicholas, 2003, "Responses to Mieke Bal's 'Visual Essentialism and the Object of Visual

Culture' : Stuff and Nonsense," Journal of Visual Culture, 2(1) : 247-9.

村尾静二, 2006, 「映像人類学の現在」村山匡一郎編『映画は世界を記録する』森話社, 246-70.

丹羽美之, 2008,「映像編集の方法と実践——映像を用いたフィールドワーク」金井明人・丹羽美

之編『映像編集の理論と実践』法政大学出版局, 145-63.

岡田晋, 1977, 「映像学と文化人類学」『季刊映像』日本映像学会, 7: 52-7.

大森康宏, 1982,「映像人類学」『現代のエスプリ別冊 現代の文化人類学』2: 85-131.

Rosaldo, Renato, 1989, Culture and Truth: The Remaking of Social Analysis, Beacon Press. (=1998,

椎名美智訳『文化と真実——社会分析の再構築』日本エディタースクール出版部. )

佐々木成明, 2005, 「映像と知覚」佐々木成明編『情報映像学入門』オーム社, 10-29.

佐藤真, 2007,「ドキュメンタリーもフィクションである」『現代思想〈総特集〉ドキュメンタリ

-』35(13): 8-13.

Sjöberg, Johannes, 2007, Transfiction (miniDV, 58mins), at 10th RAI International Festival of

Ethnographic Film, University of Manchester.

Solomon, Erez Golani, 2007, “The Urban Pathway Narrated: Daily Itineraries and Spatial Practices

in a Contemporary City - A Tokyo Study," U-MAT: Ubiquitous Media: Asian Transformations,

University of Tokyo, 15 July 2007.

田畑暁生, 2001, 「映像社会学のために一—『映像と社会』に関する覚書」『神戸大学発達科学部研 
究紀要』1:269-81.

牛島嚴, 1987 , 「日本の大学における映像人類学の現状——映像制作へ踏み込んだ 1 人の人類学者 の試行と提言」『族』筑波大学歴史人類学系民族学研究室, 3: 1-18.

亘明志・田邊信太郎, 1988, 『映像社会学序説』広島修道大学研究叢書 46 .

山中速人, 2009, 『ビデオカメラで考えよう』七つ森書館.

山中速人編, 2002, 『マルチメディアでフィールドワーク』有斐閣.

山中速人ほか, 1993, 『ビデオで社会学しませんか』有斐閣ブックス.

安川一, 2002,「“視覚的なもの”と向き合う一一視覚社会学のために」安川一ほか『視覚メディア におけるジェンダー・デイスプレイのミクロ社会学分析』(1999 2001 年度科学研究費補助金 研究成果報告書).

吉見俊哉, 2003, 『カルチュラル・ターン, 文化の政治学へ』人文書院. 


\title{
Moving Images and Societies: \\ Frontiers of visual sociology
}

\author{
ISHITA, Saeko \\ Osaka City University \\ ishita@lit.osaka-cu.ac.jp
}

The postmodern society is often characterized by overwhelming visual cultures. Here, we introduce sociology to deal with visual cultures and moving images; in other words, the mobilized and "virtual" gaze. We call this "visual sociology." Visual sociology is defined as the compound domain that regards the moving image as the method/object/practice of sociology. The interest in visual sociology has been gradually increasing since the 1980s. In the late 1990s, a series of visual studies after the cultural turn and the spread of digital tools effected together; as a result, more number of researchers began focusing on visual sociology. The visual studies after the cultural turn need to reconsider moving images as cultural constructs from the foundation.

In this article, I discuss the new frontiers of visual sociology, i.e., new research themes after the cultural turn. These research themes apply the sociological research practices to both the production and reading of visual images. I believe that both are consecutive matters. First, I examine various conditions in the sociological video-making, i.e., the production of visual images. I emphasize the mobility and fluidity of the subject to shoot sociological objects. Furthermore, I examine the methods concerning the sociological visual analysis. At the same time, I argue the transnational circulation and reception of visual images in the age of globalization.

Through pursuing this line of thought, I aim to achieve the following: (1) modify the ocular-centristic model on human beings in sociology; (2) introduce the models of various audiences and experiences of gendered bodies and not standardized bodies; and (3) open up standardized seeing and hearing experiences to the domain of broader bodily experiences.

Keywords: visual sociology, visual turn, moving images as cultural constructs 